\title{
IODOPHILIC POLYSACCHARIDE SYNTHESIS, ACID PRODUCTION AND GROWTH IN ORAL STREPTOCOCCI
}

\author{
J. vaN HoUte, K. C. WINKLER and H. M. JANSEN \\ Laboratory of Microbiology, State University, Catharijnesingel 59, \\ Utrecht, The Netherlands
}

\begin{abstract}
Summary-The relation between iodophilic polysaccharide formation, acid production and growth in a-haemolytic streptococci, isolated from human dental plaque, was studied. In experiments with resting cell suspensions, or with cells growing at a low rate, all strains synthesizing iodophilic polysaccharide were found to be more acidogenic than strains not producing iodophilic polysaccharide. The higher acid production rate of the iodophilic polysaccharide-producing strains seems to be the result of their increased demand for energy required for polysaccharide synthesis. In cultures of iodophilic polysaccharide-storing strains, with a high initial cell concentration $\left( \pm 10^{10}\right.$ cells $\left./ \mathrm{ml}\right)$, cell multiplication was delayed and did not occur before the polysaccharide content of the cells was at or near its maximal level. No such delay was observed in cultures of strains not producing iodophilic polysaccharide. With regard to the importance of iodophilic polysaccharide synthesis for the carious process, the acid production from polysaccharide degradation has, up till now, been stressed. The present results indicate that in addition to this process, also the high acid production rate of iodophilic polysaccharide-storing streptococci during polysaccharide synthesis, may increase the acidogenic potential of dental plaques containing such organisms.
\end{abstract}

\section{INTRODUCTION}

THE SYNTHESIS of iodophilic polysaccharides by oral bacteria may be an important factor in the development of dental caries. These polysaccharides are produced by the majority of the cultivable bacterial types present in the dental plaque (Gribons and Socransky, 1962; Berman and GibBons, 1966; van Houte, 1967). Their production is also a characteristic of streptococcal strains, from both human and animal origin, capable of inducing dental caries in germ-free or conventional animals (BERMAN and GibBons, 1966; GibBons et al., 1966; GibBons and LoEsChe, 1967). In such cariogenic strains, or in streptococcal strains isolated from human carious lesions, the synthesis of iodophilic polysaccharide appears, with few exceptions, to be a stable characteristic. In contrast, non-cariogenic hamster streptococci or streptococcal strains isolated from plaque of caries-inactive persons vary extremely in their ability to produce iodophilic polysaccharide (BERMAN and GiBBONS, 1966).

Bacteria synthesizing large amounts of iodophilic polysaccharide appear to be more numerous in dental plaques from caries-active persons (GIBBONS and SOCRANSKY, 1962; LoesCHe and HeNRY, 1967), in carious lesions (Berman and GibBons, 1966) or in plaque over carious enamel (Frank and Brendel, 1966), than in plaques from caries-inactive persons or in plaque located over normal enamel. Also, almost the whole streptococcal population of dental plaque or carious lesions in hamsters with rampant caries has been found to consist of strongly iodophilic polysaccharideproducing organisms (KeSTENBaUm, MurRaY and Weiss, 1962). 
With regard to the role of iodophilic polysaccharide-storing bacteria in the carious process emphasis has, so far, been placed on the prolonged production of acid from accumulated polysaccharide after the exhaustion of exogenous carbohydrate. In the present study attention has been paid to the acid production and growth by oral streptococci during iodophilic polysaccharide synthesis.

\section{MATERIALS AND METHODS}

\section{Isolation of streptococcal strains}

Dental plaque was obtained from six persons (20-35 yr of age), with sterile metal scalers, and suspended in sterile saline. After homogenization of the suspension for one minute in a homogenizor (Zwenk-0-mat), $0.1 \mathrm{ml}$ of appropriate dilutions was spread on the surface of sheep blood agar plates. After $48 \mathrm{hr}$ aerobic incubation at $37^{\circ} \mathrm{C}$ pinpoint colonies surrounded by a greenish zone and consisting of Grampositive, catalase-negative, chain-forming cocci, were restreaked on the same medium until pure strains were obtained.

Strep. mitis strain $S_{3}$ and its iodophilic polysaccharide-negative variant strain $S_{3 N}$ were obtained from Dr. R. J. GibBons, Forsyth Dental Center, Boston, U.S.A. Variant strains $S_{25 P_{1}}$ and $S_{25 P_{2}}$ were derived from strain $S_{25 N}$.

\section{Characterization of the isolates}

The utilization of various substrates, growth at $45^{\circ} \mathrm{C}$, growth in presence of 0.04 per cent potassium tellurite and gelatin liquefaction were determined in a medium consisting of: trypticase (Balt. Biol. Lab.), $1 \cdot 5$ per cent; yeast extract (Difco), 0.5 per cent; $\mathrm{NaCl}, 0.25$ per cent; $\mathrm{Na}_{2} \mathrm{HPO}_{4}$. 12 aq, 0.15 per cent; 1 -cystine, 0.02 per cent and $\mathrm{Na}_{2} \mathrm{SO}_{3}, 0.01$ per cent ( $\mathrm{pH} 7 \cdot 3$ ).

Nitrate reduction and production of indole (following procedures in the MANUAL of Microbiological Methods, 1957), growth in 6.5 per cent $\mathrm{NaCl}$ broth and survival of $60^{\circ} \mathrm{C}$ for $30 \mathrm{~min}$ were determined in a medium consisting of: trypticase (B.B.L.), 2 per cent; yeast extract (Difco), 0.5 per cent; $\mathrm{NaCl}, 0.5$ per cent and $\mathrm{K}_{2} \mathrm{HPO}_{4}$, $\mathbf{0} \cdot \mathbf{2}$ per cent ( $\mathrm{pH} 7 \cdot 2$ ). Levan formation was tested on mitis-salivarius agar plates (Difco). Bile tolerance and sensitivity for antibiotics were tested on the blood agar medium. All incubations were performed at $37^{\circ} \mathrm{C}$.

For serological grouping and typing capillary precipitation reactions were carried out with bacterial extracts prepared with the formamide method of FULLER (1938). In case of negative results Lancefield extracts were also tested. Dextran production was determined as described by DE STOPPELAAR, VAN HOUTE and DE MOOR (1967).

All isolates were maintained in a medium consisting of brain-heart infusion (Difco) supplemented with 0.1 per cent glucose and 0.05 per cent Bacto-agar. The stock cultures were kept at $4^{\circ} \mathrm{C}$ and transferred monthly.

\section{Polysaccharide production}

The iodophilic polysaccharide content of the cells was determined by measuring the extinction of the polysaccharide-iodine complex $\left(E_{\mathrm{PS}-\mathrm{I}}\right)$ in a Beckman DU 
spectrophotometer as previously described (VAN HouTE and JANSEN, 1968). The $E_{\mathrm{PS}-\mathrm{I}}$ is linearly related to the iodophilic polysaccharide content of the cells (VAN HouTe, 1967). Polysaccharide production was also tested on trypticase soy agar (B.B.L.) plates with 0.5 per cent yeast extract and 2 per cent glucose following procedures described by GiBbONS and SocransKY (1962).

\section{Preparation of resting cells}

The maintenance medium was inoculated with $0.5 \mathrm{ml}$ of the stock cultures. After $8-9 \mathrm{hr}$ incubation at $37^{\circ} \mathrm{C}, 0.1 \mathrm{ml}$ of the cultures was used to inoculate $100 \mathrm{ml}$ of growth medium, dispensed in screw-capped bottles, pre-incubated at $37^{\circ} \mathrm{C}$. The growth medium contained: trypticase (B.B.L.), 2 per cent; yeast extract (Difco), 0.5 per cent; $\mathrm{K}_{2} \mathrm{HPO}_{4}, 0.4$ per cent; $\mathrm{KH}_{2} \mathrm{PO}_{4}, 0.1$ per cent and $\mathrm{NaCl}, 0.2$ per cent (= basal medium) supplemented with 0.05 per cent glucose. The inoculated medium was incubated for 9-10 hr. Previous experiments had shown that, under the above conditions, the cultures reached the end of the exponential growth phase after 9-10 hr. After incubation, the sediment was washed three times in sterile saline. The determination of the number of bacteria by total cell count and the preparation of standardized cell suspensions, in saline or in bicarbonate buffer, were performed as previously described (VAN Houte and JANSEN, 1968). The cells thus obtained contained no iodophilic polysaccharide.

\section{Determination of acid production}

Standard $\mathrm{pH}$ titration curve. Lactic acid of known titre was added from a burette to a cell suspension of strain $S_{3}$ (cells without iodophilic polysaccharide) prepared by adding $5 \mathrm{ml}$ standardized cell suspension $\left(2 \times 10^{10}\right.$ cells $\left./ \mathrm{ml}\right)$ in saline, to $14.5 \mathrm{ml}$ buffer solution and $0.5 \mathrm{ml}$ distilled water. After each addition the $\mathrm{pH}$ was read (Philips PS 9400/10 pH meter). A standard line, representing the relation between $\mathrm{pH}$ and the amount of lactic acid added, was thus obtained.

Warburg procedure. The acid production was measured utilizing conventional Warburg procedures by determining the $\mathrm{CO}_{2}$ evolution from a $\mathrm{CO}_{2} / \mathrm{HCO}_{3}$ - buffer by the acid formed (UMBREIT, BURRIS and STAUFFER, 1964). Experiments were performed with 95 per cent $\mathrm{N}_{2}$ and 5 per cent $\mathrm{CO}_{2}$ in the gas phase at $37^{\circ} \mathrm{C}$ (equilibrium

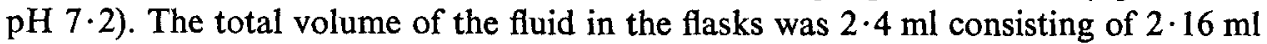
cell suspension in $\mathrm{NaHCO}_{3}$ buffer ( $\mathrm{pH} \mathrm{7 \cdot 1)}, 0 \cdot 14 \mathrm{ml}$ phosphate buffer $\left(\mathrm{Na}_{2} \mathrm{HPO}_{4}\right.$ and $\mathrm{KH}_{2} \mathrm{PO}_{4}, 0.067 \mathrm{M} ; \mathrm{pH} \mathrm{6.8)}$, and $0.1 \mathrm{ml}$ glucose solution (final molarity in flask fluid $0.056 \mathrm{M}$ ) which was tipped in from one of the sidearms just before the reading was started. It was previously established (VAN HouTE, 1967) that cells without iodophilic polysaccharide, such as were used, did not produce acid from endogenous metabolism. The phosphate was added as little or no iodophilic polysaccharide was produced in its absence. Its influence on the $\mathrm{CO}_{2}$ evolution from acid production was determined by adding $0.1 \mathrm{ml}$ of $\mathrm{H}_{2} \mathrm{SO}_{4}$ solutions of various concentration to cell suspensions under experimental conditions. A reference line, representing the relation between the added amount of acid and the amount of $\mathrm{CO}_{2}$ evolution observed, was used for correction. 
To determine the experimental error of the Warburg method, the acid production ( $\mu$ moles $\mathrm{CO}_{2}$ ) by five separate samples from each of three cell suspensions (strain $S_{3 N}$ ) was determined under experimental conditions. The means of each series of experiments were: $3 \cdot 33 \mu$ moles $\mathrm{CO}_{2}(s=0 \cdot 212$ or $\pm 6 \cdot 4$ per cent $), 2 \cdot 77 \mu$ moles $\mathrm{CO}_{2}(s=0.145$ or \pm 5.2 per cent $)$ and $3 \cdot 10 \mu$ moles $\mathrm{CO}_{2}(s=0.174$ or \pm 5.6 per cent). The standard error $(s)$ had an average of $5 \cdot 6$ per cent.

Buffer solution. The buffer solution used throughout consisted of $\mathrm{K}_{2} \mathrm{HPO}_{4}$, $4 \cdot 35 \mathrm{~g} / 1 ; \mathrm{KH}_{2} \mathrm{PO}_{4}, 3 \cdot 40 \mathrm{~g} / \mathrm{l}$ and $\mathrm{MgSO}_{4}, 0 \cdot 246 \mathrm{~g} / 1$, unless noted otherwise.

\section{Characteristics of the strains}

\section{RESULTS}

All isolates consisted of Gram-positive, $\alpha$-haemolytic, facultative cocci, in general forming short chains and giving rise to small, greyish-white colonies on blood agar. None of the isolates produced catalase, indole or reduced nitrate. No growth was observed in 6.5 per cent $\mathrm{NaCl}$ broth, at $45^{\circ} \mathrm{C}$, after $30 \mathrm{~min}$ at $60^{\circ} \mathrm{C}$, in presence of 0.04 per cent potassium tellurite or in 0.1 per cent methylene blue milk. Gelatin was not liquefied; levan was not formed.

Litmus milk was acidified, reduced and coagulated. All strains were sensitive to tetracycline, chloramphenicol, penicillin and streptomycin except strains $S_{1}$ and $S_{25 N}$ which were not sensitive to penicillin and strains $S_{8}, S_{21}$ and $S_{25 N}$ which were not sensitive to streptomycin.

Glucose, maltose, sucrose, lactose, fructose, mannose and galactose were fermented but not arabinose, xylose, sorbitol, mannitol, glycerol, inositol, dulcitol, adonitol or erythritol. Sodium hippurate was not hydrolysed. Gas was not formed. The final $\mathrm{pH}$ ranged from $3 \cdot 9$ to $4 \cdot 5$. Characteristics which were variable, together with other data, are given in Table 1.

Extracts of strains $S_{4}, S_{13}$ and $S_{26}$ reacted with antiserum against the English group $H$ strain $(N C T C 7868)$. Group $H(E)$ nglish strains are serologically identical to Strep. sanguis type I (NCTC 7863) or Strep. s.b.e. (WHITE and NIVEN, 1946). Strains $S_{2}$ and $S_{23}$ reacted with antiserum prepared against strain $N C T C 5338\left(K_{2}\right)$. Strains $S_{15}$ and $S_{21}$ reacted with antiserum against strain NCTC 7864 (Strep. sanguis type II, SII). Extracts of strains $S_{8}, S_{9}, S_{10}, S_{14}, S_{19}, S_{24}$ and $S_{25 N}$ reacted with antiserum against Strep. $M G, N C T C 8037$ (MIRICK et al., 1944a, b, c) having both group $F$ and type III antigens (WILLERS, OTTENS and MICHEL, 1964) and against the non-haemolytic streptococcus, strain R.I.V. 216 with type III antigen only. They did not react with group $F$ serum, however, and were consequently classified as z3III strains (MiCHEL et al., 1967). The other strains reacted with none of the major group antisera.

The iodophilic polysaccharide content of cells of the strains, cultivated for $16 \mathrm{hr}$ in basal medium with 1 per cent glucose, was measured at various times after primary isolation (Table 1, $E_{\mathrm{PS}-\mathrm{I}}$, columns I-IV). Many strains were found to be variable with respect to polysaccharide production. Strains originally forming little or no polysaccharide $\left(E_{\mathrm{PS}-\mathrm{I}}<0 \cdot 10\right)$ became good producers after repeated transfer in the maintenance medium; the reverse also occurred. This variability was accompanied by 

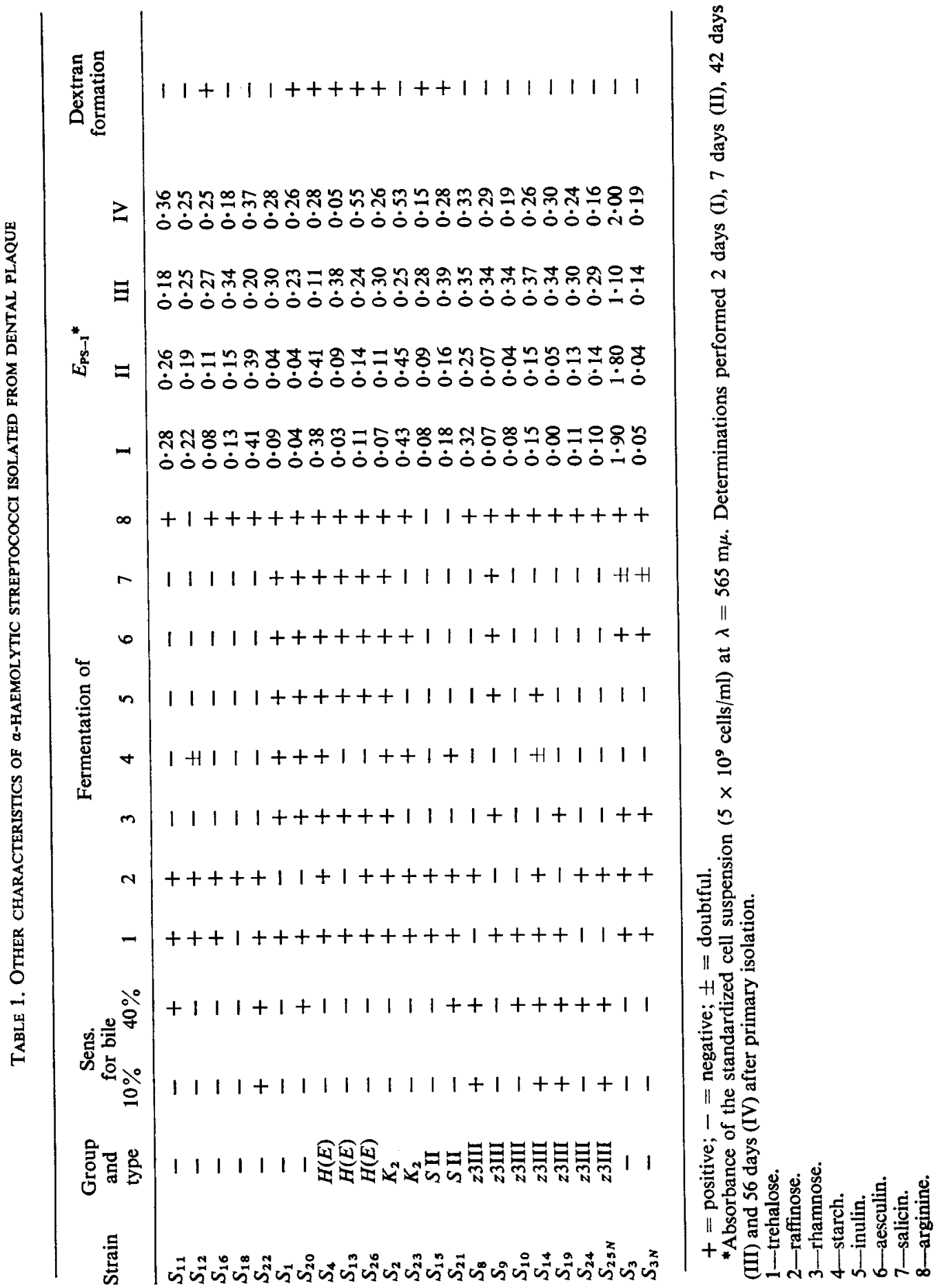
the appearance of mixtures of strong, weak and negative iodine-staining colonies on 2 per cent glucose plates. No differences in biochemical properties between strains $S_{3}$ and $S_{3 N}$ (Table 1) or between strain $S_{25 N}$, which was negative on primary isolation, and its positive variants were observed. Similar observations have been made by BERMAN and GibBons (1966), although the mechanism responsible for this variation remains unclear.

From the 21 isolates, 8 strains produced dextran (Table 1). In the case of strains $S_{2}$ and $S_{20}$ it could only be demonstrated with type II pneumococcus antiserum; the other strains, in addition, markedly increased the viscosity of the medium.

Due to the variable iodophilic polysaccharide production, and for purpose of the following experiments, additional strains of streptococci were isolated from dental plaque of the same persons. The colonies of these strains (designated $S_{27}, S_{28}, S_{29}$ and $S_{30}$ ), if cultivated on 2 per cent glucose plates, did not colour with iodine solution, indicating the absence of iodophilic polysaccharide. All strains were Gram-positive, $a$-haemolytic, facultative, chain-forming cocci, forming pinpoint colonies on blood agar. None of the strains produced catalase, indole or reduced nitrate. No growth was observed at $45^{\circ} \mathrm{C}$, after $30 \mathrm{~min}$ at $60^{\circ} \mathrm{C}$, in 6.5 per cent $\mathrm{NaCl}$ broth or in presence of 0.04 per cent potassium tellurite. Litmus milk was acidified, reduced and coagulated. Glucose, maltose, sucrose, fructose and lactose were fermented. Levan was not formed.

\section{ACID PRODUCTION AND IODOPHILIC POLYSACCHARIDE SYNTHESIS}

\section{Resting cell experiments}

Five millilitres of each of standardized cell suspensions of strains $S_{3}$ and $S_{3 N}\left(2 \times 10^{10}\right.$ cells $/ \mathrm{ml})$ and strains $S_{25 N}, S_{25 P_{1}}$ and $S_{25 P_{2}}\left(10^{10}\right.$ cells $\left./ \mathrm{ml}\right)$, prepared in saline, were added to $14.5 \mathrm{ml}$ buffer solution in screw-capped bottles. After temperature equilibration for $10 \mathrm{~min}$ in a waterbath at $37^{\circ} \mathrm{C}, 0.5 \mathrm{ml}$ glucose solution (final concentration

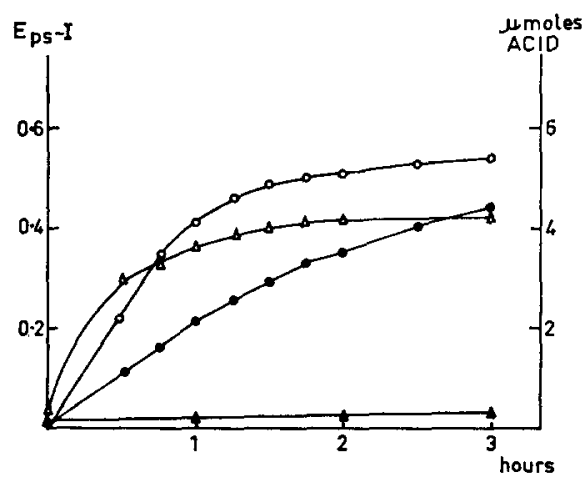

Fig. 1. Iodophilic polysaccharide formation and acid production by strains $S_{3}$ and $S_{3 N}$. $E_{\mathrm{PS}-1}\left(10^{9}\right.$ cells $\left./ \mathrm{ml}\right): S_{3}(\triangle)$ and $S_{3 N}(\Delta)$ $\mu$ moles acid $\left(10^{9}\right.$ cells): $S_{3}(O)$ and $S_{3 N}(O)$. 
1 per cent) was added (time $0 \mathrm{~min}$ ). The initial $\mathrm{pH}$ was $6 \cdot 95$. Samples were removed periodically to measure the $\mathrm{pH}$ and the $E_{\mathrm{PS}-\mathrm{I}}$; the standard curve was used to calculate the acid production.

It was found (Fig. 1) that the acid production rate of the rapidly polysaccharide synthesizing strain $S_{3}$ was much higher than that of the negative variant strain $S_{3 N}$. During the first hour, strain $S_{3}$ produced over twice the amount of acid of strain $S_{3 N}$. Thereafter, the acid production rate of strain $S_{3}$ diminished, due to the low $\mathrm{pH}$ $(<5 \cdot 0)$, while the rate of acid production of strain $S_{3 N}$ remained about the same (pH after $1 \mathrm{hr}: 6 \cdot 3$ ). Analogous results were obtained with strain $S_{25 N}$ and its positive variants (Fig. 2). Strain $S_{25 N}$ produced far less acid than strains $S_{25 P_{1}}$ or $S_{25 P_{2}}$.

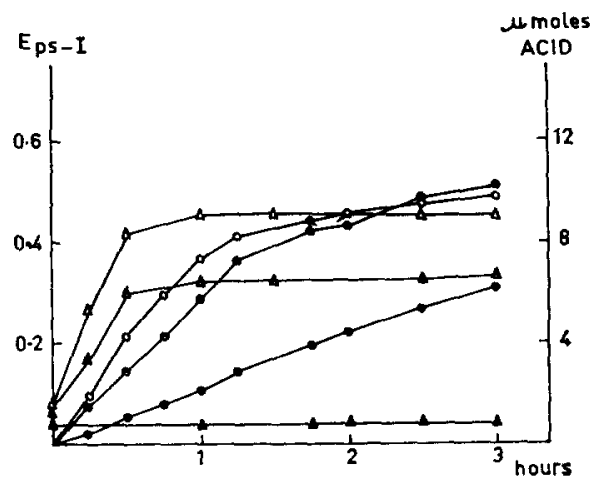

FIG. 2. Iodophilic polysaccharide formation and acid production by strains $S_{25 N}, S_{25 p_{1}}$ and $S_{25 P_{2}}$. $E_{\mathrm{PS}-\mathrm{I}}\left(10^{9}\right.$ cells $\left./ \mathrm{ml}\right): S_{25 P_{1}}(\triangle) ; S_{25 P_{2}}(\Delta)$ and $S_{25 N}(\mathrm{~A})$ $\mu$ moles acid $\left(10^{9}\right.$ cells): $S_{25 P_{1}}(O) ; S_{25 P_{2}}(\Theta)$ and $S_{25 N}(O)$.

The relation between acid production and polysaccharide formation was also studied in a number of other strains. The acid production was measured under anaerobic conditions in the Warburg apparatus. The strains were placed into three groups according to their ability to form iodophilic polysaccharide (Table 2). The strong polysaccharide-producing strains were placed in group I, the strains producing lesser amounts of polysaccharide in group II and the strains unable to form polysaccharide in group III. The highest acid production rate was observed in the strong polysaccharide-producing strains, while the acid production rate was lower in the strains producing less polysaccharide. The least amount of acid was formed by the polysaccharide-negative strains. The differences between the means of the three groups were statistically significant $(P<0 \cdot 001)$ (Student's $t$-test).

The same relation between acid production and polysaccharide synthesis was observed with the iodophilic polysaccharide-variable strain $S_{2}$ while the previously obtained results with strains $S_{3}, S_{3 N}$ and $S_{25 N}$ and its positive variants were confirmed (Table 3). 


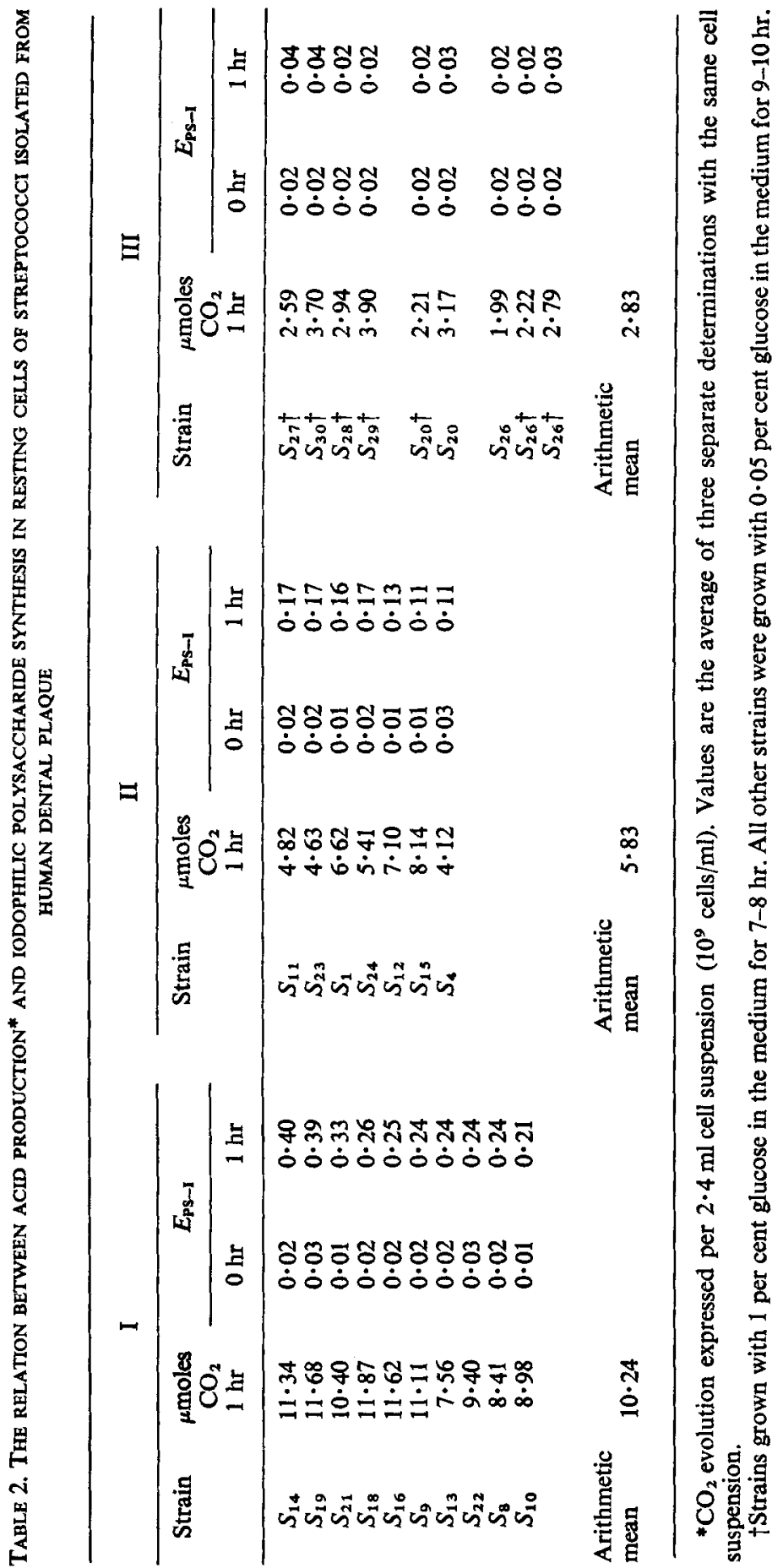


IODOPHILIC POLYSACCHARIDE SYNTHESIS, ACID PRODUCTION AND GROWTH IN ORAL STREPTOCOCCI 53

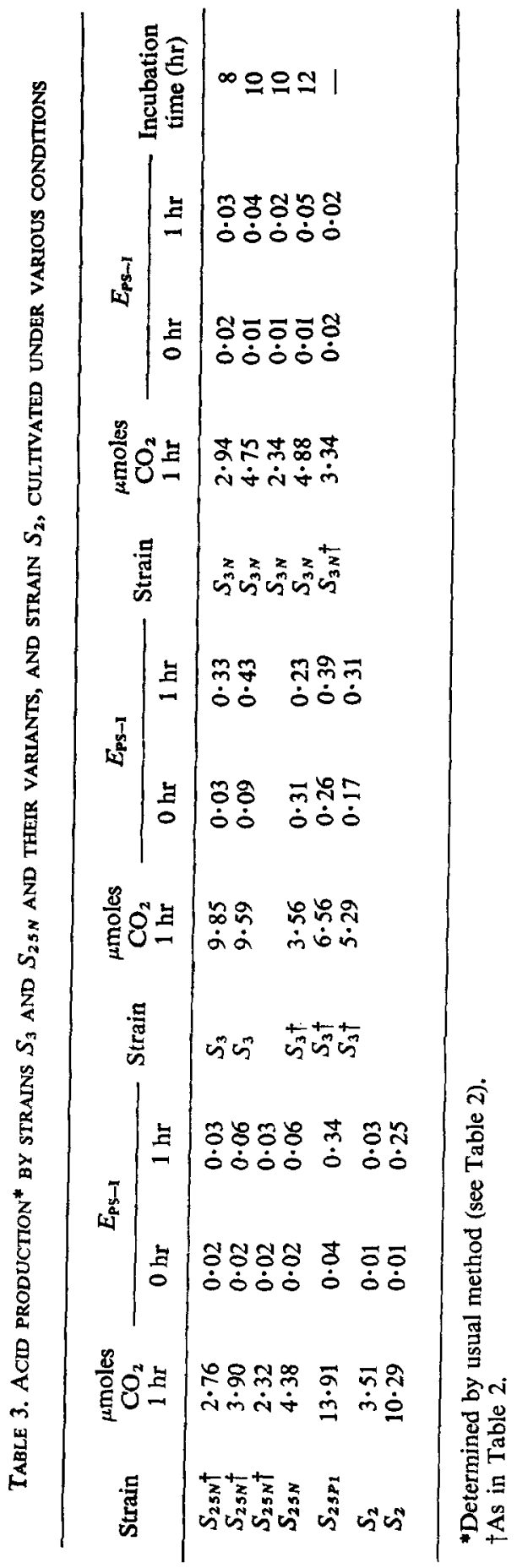


To exclude the possibility of impaired viability due to prolonged incubation (STRÁLFORS, 1950), the cells were harvested before the stationary growth phase was reached while the $\mathrm{pH}$ of the growth medium never fell below $6 \cdot 5$. Repeated testing of the strains did not reveal any essential differences in acid production.

Also, cells cultivated in the medium with 0.05 per cent glucose for $10 \mathrm{hr}$ or harvested from an exponentially growing culture with 1 per cent glucose $(\mathrm{pH} \geqslant 6 \cdot 3)$, both showed a low acid production as illustrated with the strains of group III (Table 2) and strains $S_{25 N}$ and $S_{3 N}$ (Table 3). In addition, no marked difference was observed in the metabolic activity of strain $S_{3 N}$ cultivated for 8,10 or $12 \mathrm{hr}$ with 0.05 per cent glucose in the medium (Table 3 ).

It was further observed that cells of strain $S_{3}$, harvested during exponential growth in medium with 1 per cent glucose, already containing large amounts of polysaccharide, produced about the same amount of acid as the cells of strain $S_{3 N}$ (Table 3).

\section{Experiments with growing cells}

The relationship between acid production and polysaccharide synthesis was also investigated under conditions whereby the cells of the concentrated cell suspensions were permitted to grow at various rates. Strains $S_{3 L}, S_{3 N}, S_{25 N}$ and $S_{25 P_{1}}$ were used. Strain $S_{3 L}$ was a culture of strain $S_{3}$, lyophilized shortly after receipt from Dr. R. J. GrbBons. Two different growth media were used: the basal medium and the basal medium without yeast extract and with one third of the trypticase concentration. The strains were grown in the basal medium with 0.05 per cent glucose for $10 \mathrm{hr}$. The cells were washed three times in sterile saline and $10^{10}$ cells $/ \mathrm{ml}$ were suspended in the medium in screw-capped bottles. After $10 \mathrm{~min}$ pre-incubation of the inoculated medium in the waterbath at $37^{\circ} \mathrm{C}$, glucose was added to a final concentration of 2 per cent (time $0 \mathrm{~min}$ ). Periodically, the $\mathrm{pH}$, the number of bacteria per millilitre culture and the $E_{\mathrm{PS}-\mathrm{I}}$ were determined. For the latter procedure, part of the culture was centrifuged, the sediment taken up in buffer and the suspension adjusted to the desired cell concentration.

The result with strains $S_{3 L}$ and $S_{3 N}$ in basal medium is shown in Fig. 3. The cells of strain $S_{3 L}$ rapidly accumulated polysaccharide but did not increase in number during the first hour; multiplication started when the cells reached their maximal polysaccharide content $\left(\sim E_{\mathrm{PS}-\mathrm{I}}= \pm 0 \cdot 6\right)$. The cells of strain $S_{3 N}$, however, commenced to multiply immediately after the addition of glucose. The cells of strain $S_{3 L}$ produced more acid than the cells of strain $S_{3 N}$, as indicated by the $\mathrm{pH}$ curves. The amount of acid, determined by titration with $\mathrm{NaOH}(0 \cdot 1 \mathrm{~N})$ at the end of the experimental period, was $29 \cdot 21 \mu$ moles $/ \mathrm{ml}$ for the culture of strain $S_{3 L}$ as compared to 23.42 $\mu$ moles $/ \mathrm{ml}$ for strain $S_{3 N}$; this notwithstanding the fact that during the whole experimental period the cell concentration was considerably higher in the latter culture.

Analogous results were obtained with strains $S_{3 L}$ and $S_{3 N}$ in the basal medium without yeast extract and decreased trypticase content. In this medium, strain $S_{3 N}$ grew at a much lower rate (Fig. 4). At the end of the experimental period $32 \cdot 64 \mu$ moles 


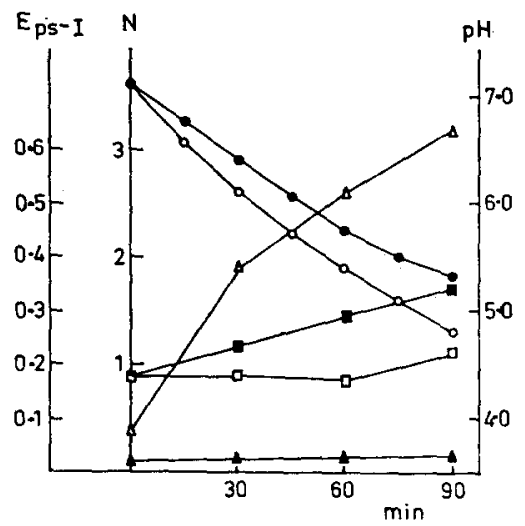

Fig. 3. Iodophilic polysaccharide formation, acid production and growth by strains $S_{3 L}$ and $S_{3 N}$. $E_{\mathrm{PS}-\mathrm{I}}\left(2 \times 10^{9}\right.$ cells $\left./ \mathrm{ml}\right): S_{3 L}(\triangle)$ and $S_{3 N}(\Delta)$ $N$ (number of cells $\left.\times 10^{10} / \mathrm{ml}\right): S_{3 L}(\square)$ and $S_{3 N}(\square)$. $\mathrm{pH}: S_{3 L}(\mathrm{O})$ and $S_{3 N}(O)$.

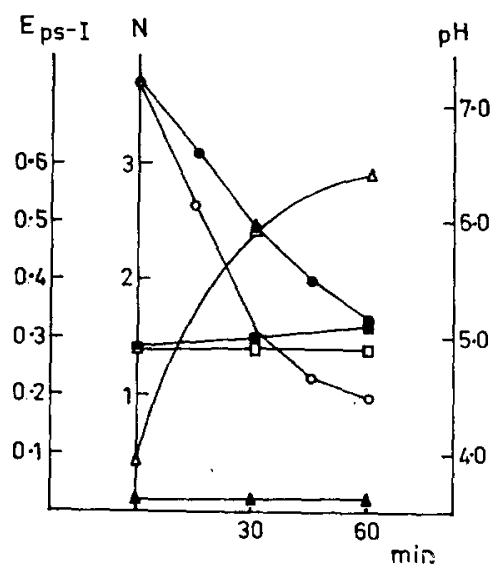

FIG. 4. Iodophilic polysaccharide formation, acid production and growth by strains $S_{3 L}$ and $S_{3 N}$.

$E_{\mathrm{PS}-1}\left(2 \times 10^{9}\right.$ cells $\left./ \mathrm{ml}\right): S_{3 L}(\triangle)$ and $S_{3 N}(\Delta)$

$N$ (number of cells $\times 10^{10} / \mathrm{ml}$ ): $S_{3 L}(\square)$ and $S_{3 N}(\square)$ $\mathrm{pH}: S_{3 L}(\mathrm{O})$ and $S_{3 N}(O)$.

and $23.88 \mu$ moles of acid were formed per millilitre culture of strains $S_{3 L}$ and $S_{3 N}$ respectively. The result from the experiment with strains $S_{25 N}$ and $S_{25 P_{1}}$ in the basal medium is shown in Fig. 5. The $\mathrm{pH}$ in the culture of strain $S_{25 P_{1}}$ fell much more rapidly than in the culture of strain $S_{25 N}$ and after $1 \mathrm{hr} 40 \cdot 12 \mu$ moles acid were formed per millilitre of the culture of strain $S_{25 P_{1}}$, as compared to only $11 \cdot 16 \mu$ moles/ $\mathrm{ml}$ of the culture of strain $S_{25 N}$. 


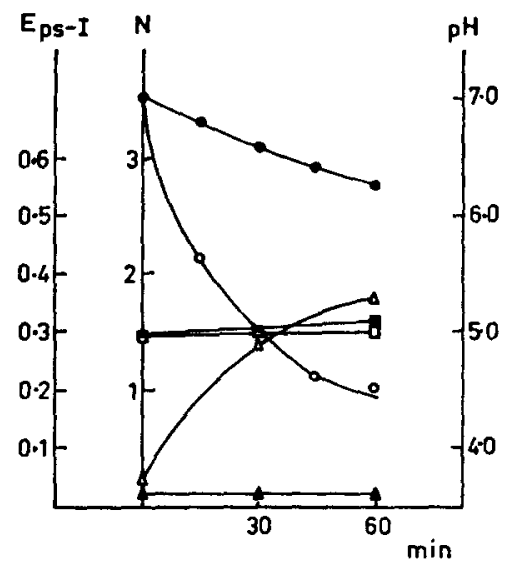

Fig. 5. Iodophilic polysaccharide formation, acid production and growth by strains $S_{25 N}$ and $S_{25 P_{1}}$.

$E_{\mathrm{PS}-1}\left(2 \times 10^{9} \mathrm{cells} / \mathrm{ml}: S_{2 S P_{1}}(\triangle)\right.$ and $S_{2 S N}(\mathrm{~A})$

$N$ (number of cells $\left.\times 10^{10} / \mathrm{ml}\right): S_{2 S P_{1}}(\square)$ and $S_{25 N}(\square)$

pH: $S_{25 P_{1}}(O)$ and $S_{25 N}(O)$.

\section{MONOPHASIC AND BIPHASIC IODOPHILIC POLYSACCHARIDE SYNTHESIS}

In previous experiments it was found that cells not producing polysaccharide commenced to grow earlier than polysaccharide-producing cells. This fact had been consistently observed in other, similar, experiments. In addition, initiation of growth in cultures of polysaccharide-producing cells, coincided, in general, with the moment when the cells had accumulated most of their polysaccharide. GibBONS and KAPSIMALIS (1963) found, however, that strain $S_{3}$ stored polysaccharide early during growth, but that during exponential growth no further synthesis of polysaccharide occurred. A second increase in polysaccharide content of the cells occurred when the culture entered the stationary growth phase. Thus, our cells produced polysaccharide to their maximal capacity before growth started while GrbBons and Kapsimalis (1963) observed growth before the cells had reached their maximal polysaccharide content.

It was also observed that strain $S_{3}$, as well as other strains, upon frequent transfer in the maintenance medium, increased their ability to produce polysaccharide. The production of polysaccharide during growth was, therefore, studied with strain $S_{3 L}$ and a culture of strain $S_{3}$ which had been often transferred in the maintenance medium. Cultures of both strains grown in the basal medium with 0.05 per cent glucose for $10 \mathrm{hr}$ were used as a source of inoculum. Periodically, during growth in the basal medium with 2 per cent glucose, the cell concentration and the $E_{\mathrm{PS}-1}$ were determined as previously.

It may be seen (Fig. 6) that strain $S_{3}$ synthesized polysaccharide at a high rate until the polysaccharide content of the cells had reached its maximum, after which 


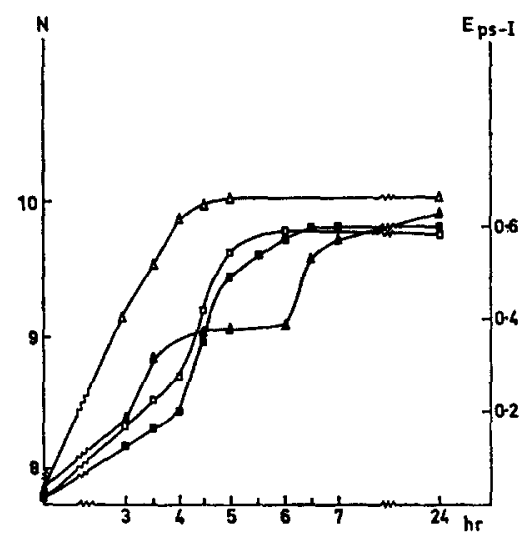

Fig. 6. Iodophilic polysaccharide formation by strains $S_{3}$ and $S_{3 L}$ during growth.

$E_{\mathrm{PS}-\mathrm{I}}\left(2 \times 10^{9}\right.$ cells $\left./ \mathrm{ml}\right): S_{3}(\triangle)$ and $S_{3 L}(\Delta)$

$N\left(\log _{10}\right.$ number of cells $\left./ \mathrm{ml}\right): S_{3}(\square)$ and $S_{3 L}(\square)$.

the cells began to divide rapidly. Strain $S_{3 L}$, on the other hand, initially produced polysaccharide at a much lower rate than strain $S_{3}$, while during the exponential growth phase the polysaccharide content of the cells remained at the same level. A second increase in polysaccharide content, however, occurred at the end of the exponential growth phase.

\section{DISCUSSION}

The iodophilic polysaccharide produced by various types of streptococci, present in human dental plaque, has been shown to be intracellular and to belong to the class of the glycogen-type polysaccharides (GibBONS and KAPSIMALIS, 1963; VAN HouTE and JANSEN, 1968).

GibBons (1964a) showed that cells of strain $S_{3}$, containing iodophilic polysaccharide, were capable of inducible enzyme synthesis in contrast to cells of strain $S_{3}$ devoid of iodophilic polysaccharide. Recently, it has also been found that the endogenous metabolism of cells of strain $S_{3}$, or other strains of streptococci, is quantitatively dependent on their iodophilic polysaccharide content (VAN HOUTE, 1967). It appears, therefore, that the intracellular iodophilic polysaccharide serves as the sole source of energy reserve in these organisms.

The studies on the synthesis of polysaccharides of the glycogen class by bacteria (HoRECKER, 1966) and by Streptococcus mitis, including strain $S_{3}$ (WALKER, 1966), strongly indicate that polysaccharide synthesis from glucose proceeds via glucose-6phosphate, glucose-1-phosphate, adenosine diphosphate-glucose and the transfer of glucosyl residues from adenosine diphosphate-glucose to glycogen-like primers. Thus, the conversion of one mole of glucose into polysaccharide would require two moles of adenosine triphosphate (ATP).

The bacterial concentration in the dental plaque is very high and in the order of $2 \cdot 5-4 \times 10^{10}$ cultivable cells per gram (STRÅLFORS, 1950; GibBONs et al., 1964). 
Due to the intermittent nature of food exposure or the presence of inhibitory substances, bacterial growth presumably proceeds at an over-all slow rate; the organisms may only average a few divisions a day (GiBbons, 1964b). Therefore, our experiments were performed with high cell concentrations under conditions whereby the cells were either in the resting state or permitted to grow at various rates.

\section{Polysaccharide synthesis and acid production}

In our own experiments, with resting and growing cells, all strains producing iodophilic polysaccharide were much more acidogenic than strains not producing iodophilic polysaccharide. This observation, especially in case of strains $S_{3}$ and $S_{3 N}$, and strain $S_{25 N}$ and its polysaccharide-positive variants, suggests that polysaccharide synthesis is related to the increased acid production. This is also supported by the fact that cells, already containing polysaccharide, exhibited a low acid production rate similar to cells not producing polysaccharide. The resting cells in our experiments contained little or no polysaccharide initially and are assumed to have a low ATP content. The polysaccharide content of cells of streptococci, allowed to accumulate polysaccharide, may constitute over 50 per cent of the total dry weight of the cells (GIBBONS, 1964a; VAN HouTE, 1967), while 35 per cent of the total glucose utilized is converted into polysaccharide (WEISS et al., 1965). Therefore, polysaccharide synthesis by the cell places a great demand on the available ATP which may result in an increased rate of glycolysis.

Among the strains, which have been studied, streptococci which produced polysaccharide, were always more acidogenic than streptococci not producing polysaccharide. However, the possibility that strongly acidogenic streptococci which do not produce polysaccharide could be present in the dental plaque cannot be completely excluded.

The synthesis of iodophilic polysaccharide in the dental plaque, in presence of a suitable substrate, proceeds at an extremely rapid rate (CRITCHLEY et al., 1967). It would seem, therefore, that upon carbohydrate intake the presence of many organisms capable of iodophilic polysaccharide synthesis would result in a more rapid $\mathrm{pH}$ decrease, and possibly a lower final $\mathrm{pH}$, in the dental plaque than in the absence of such organisms. The presence of exogenous carbohydrate under conditions whereby the organisms already contained significant amounts of polysaccharide would tend to diminish the difference in acid production rate between polysaccharide-producing and non-polysaccharide-producing organisms. The subsequent increase in polysaccharide content of the polysaccharide-producing cells, however, would later, upon depletion of the environmental carbohydrate, result in more acid production from polysaccharide degradation. Either way, bacterial polysaccharide synthesis could be responsible for a significant increase in the acidogenic potential of dental plaques containing high numbers of polysaccharide-producing organisms.

\section{Polysaccharide synthesis and growth}

FORREST (1965) and FORREST and WALKER (1965) measured the level of the ATP pool in Strep. faecalis during growth. It appeared that if the ATP pool level fell 
below a certain critical figure, exponential growth ceased. It was suggested by these investigators that a certain amount of ATP should be present to provide energy for all the synthetic processes occurring during growth.

In our experiments with high concentrations of cells of strain $S_{3 L}$, under growth conditions, cell division did not occur before the polysaccharide content of the cells was at or near its maximal level. Strain $S_{3 N}$, not producing polysaccharide, consistently commenced to grow earlier than strain $S_{3 L}$. This may indicate that the ATP generated by the cells of strain $S_{3 L}$, initially low in ATP, was first mainly utilized for polysaccharide formation. Upon the slowing down of this process more ATP would become available for the synthetic processes required for growth. The cells of strain $S_{3 N}$, on the other hand, could use all the available ATP only for purpose of growth. However, the balance between the amount of energy available for polysaccharide production or for growth is not always the same. This is indicated by the difference in polysaccharide production between strain $S_{3 L}$ and the frequently transferred strain $S_{3}$ (Fig. 6); and also by the different manner in which polysaccharide synthesis by strain $S_{3 L}$ proceeded in growth medium with very high (Fig. 3) or much lower initial cell concentrations (Fig. 6). The mechanism of this regulation has not yet been studied.

In the experiments with high cell concentrations, such as occur in the dental plaque, the iodophilic polysaccharide-producing streptococci commenced to multiply later than streptococci unable to produce polysaccharide. Therefore, the question could be raised whether the former would not be outgrown by the latter. This apparently does not occur since polysaccharide-producing streptococci frequently constitute a significant proportion of the dental plaque flora. The accumulated polysaccharide could be used for growth by the cell (GIBBONs, 1964a) and thus compensate for the possible delay in multiplication. In addition, the presence of polysaccharide may prevent the breakdown of other internal cell constituents in periods of nutrient exhaustion and favour the survival of the organism as has been observed in Aerobacter aerogenes (STRANGE, DARK and NESS, 1961). The role of iodophilic polysaccharide in relation to survival is under investigation at present.

Acknowledgements-The authors wish to thank Dr. C. E. DE MOOR for his assistance in the serological identification of the used organisms and Professor O. BACKER DIRKs for his valuable advice.

\footnotetext{
Résumé-Le rapport entre la formation de polysaccharide iodophile, la production d'acide et la croissance de streptocoques a-hémolytiques, isolés à partir de plaques dentaires humaines, est étudié. Des essais effectués à l'aide de suspensions cellulaires, au repos, ou de bactéries à croissance lente montrent que toutes les espèces susceptibles de synthétiser des polysaccharides iodophiles, produisent plus d'acides que les espèces ne produisant pas de tels polysaccharides. La production acide plus élevée parait liée aux besoins énergétiques plus élevés, nécessaires à la synthèse polysaccharidique. Dans les cultures d'espèces bactériennes, à concentrationcellulaire initiale élevée $\left( \pm 10^{10}\right.$ cellules $/ \mathrm{ml}$ ) et mettant en réserve des polysaccharides, la division cellulaire est retardée et ne commence que lorsque le contenu en polysaccharides est voisin de la concentration maximale. Un tel retard dans la division cellulaire n'est pas observè dans des cultures bactériennes ne produisant pas de polysaccharides iodophiles. En ce qui concerne l'importance de la synthèse de polysaccharides iodophiles pour le processus carieux, il
} 
apparait que la production d'acides, faisant suite à la dégradation des polysaccharides, est importante. En outre, il semble que la production élevée d'acides par des streptocoques, mettant en réserve des polysaccharides iodophiles, contribue à augmenter le potentiel acidogénique des plaques dentaires.

Zusammenfassung-An a-haemolysierenden Streptokokken, die aus menschlichen Zahnplaques isoliert worden waren, wurde die Beziehung zwischen jodophiler Polysaccharidbildung, Säureproduktion und Wachstum untersucht. In Versuchen mit ruhenden Zellsuspensionen oder mit langsam wachsenden Zellen zeigten alle jodophile Polysaccharide synthetisierenden Stämme mehr Säurebildung als solche Stämme, die nicht jodophile Polysaccharide entwickelten. Die größere Säurebildungsgeschwindigkeit der jodophile Polysaccharide bildenden Stämme scheint die Folge ihres gesteigerten Bedarfs an für die Polysaccharidsynthese benötigter Energie zu sein. In Kulturen von jodophile Polysaccharide speichernden Stämmen mit einer hohen Anfangskonzentration an Zellen ( $\pm 10^{10} \mathrm{Zellen} / \mathrm{ml}$ ) hörte die Zellvermehrung auf und trat nicht wieder ein, bevor der Polysaccharidgehalt der Zellen unmittelbar oder nahezu das Maximum erreichte. Eine derartige Unterbrechung wurde nicht in Kulturen von solchen Stämmen beobachtet, die keine jodophilen Polysaccharide bildeten. Hinsichtlich der Wichtigkeit der jodophilen Polysaccharidsynthese für den kariösen Prozess wurde bis jetzt die Säurebildung aus dem Polysaccharidabbau in den Vordergrund gestellt. Die vorliegenden Ergebnisse weisen darauf hin, daß zusätzlich zu diesem Vorgang auch die hohe Säurebildungsgeschwindigkeit der jodophile Polysaccharide speichernden Streptokokken während der Polysaccharidsynthese das Säurepotential der Zahnplaques, die solche Organismen enthält, zu erhöhen vermag.

\section{REFERENCES}

BERMAN, K. S. and GibBons, R. J. 1966. Iodophilic polysaccharide synthesis by human and rodent oral bacteria. Archs oral Biol. 11, 533-542.

Critchley, P., Wood, J. M., Saxton, C. A. and Leach, S. A. 1967. The polymerisation of dietary sugars by dental plaque. Caries Res. 1, 112-129.

FORREST, W. W. 1965. Adenosine triphosphate pool during the growth cycle in Streptococcus faecalis. J. Bact. 90, 1013-1018.

FORREST, W. W. and WALKER, D. J. 1965. Control of glycolysis in washed suspensions of Streptococcus faecalis. Nature, Lond. 207, 46-48.

Frank, R. M. and Brendel, A. 1966. Ultrastructure of the approximal dental plaque and the underlying normal and carious enamel. Archs oral Biol. 11, 883-912.

FULLER, A. T. 1938. The formamide method for the extraction of polysaccharides from haemolytic streptococci. Br. J. exp. Path. 19, 130-139.

GibBons, R. J. 1964a. Metabolism of intracellular polysaccharide by Streptococcus mitis and its relation to inducible enzyme formation. J. Bact. 87, 1512-1520.

GiBbons, R. J. 1964b. Bacteriology of dental caries. J. dent. Res. 43, 1021-1028.

GrbBons, R. J. and Kapsimalis, B. 1963. Synthesis of intracellular iodophilic polysaccharide by Streptococcus mitis. Archs oral Biol. 8, 319-329.

GibBons, R. J. and LoEsCHE, W. J. 1967. Isolation of cariogenic streptococci from Guatemalan children. Archs oral Biol. 12, 1013-1014.

GibBons, R. J. and SoCRANSKy, S. S. 1962. Intracellular polysaccharide storage by organisms in dental plaques. Archs oral Biol. 7, 73-80.

Gibbons, R. J., Berman, K. S., Knoettner, P. and Kapsimalis, B. 1966. Dental caries and alveolar bone loss in gnotobiotic rats infected with capsule forming streptococci of human origin. Archs oral Biol. 11, 549-560.

Gibbons, R. J., Socransky, S. S., De Araujo, W. C. and van Houte, J. 1964. Studies of the predominant cultivable microbiota of dental plaque. Archs oral Biol. 9, 365-370.

HoreCKer, B. L. 1966. The biosynthesis of bacterial polysaccharides. Ann. Rev. Microbiol. 20, 253-290.

Kestenbaum, R. C., Murray, T. J. and Weiss, S. 1962. The incidence of polysaccharide storing streptococci in carious lesions of hamsters. Internat. Ass. for Dent. Res. Preprinted abstracts, 42nd General Meeting, Abstract No. 23:7. 
LOESCHE, W. J. and HeNRY, C. A. 1967. Intracellular microbial polysaccharide production and dental caries in a Guatemalan Indian village. Archs oral Biol. 12, 189-194.

Manual of Microbiological Methods, 1957. McGraw-Hill, New York.

Michel, M. F., DE Moor, C. E., OtTens, H., Willers, J. M. N. and Winkler, K. C. 1967. A note on the nomenclature of certain polysaccharides resembling the group antigens of streptococci. J. gen. Microbiol. 49, 49-51.

Mirick, G. S., Thomas, L., Curnen, E. C. and Horsfall Jr., F. L. 1944a. Studies on a non-hemolytic streptococcus isolated from the respiratory tract of human beings. I. Biological characteristics of Streptococcus MG. J. exp. Med. 80, 391-406.

Mrrick, G. S., Thomas, L., Curnen, E. C. and Horsfall Jr., F. L. 1944b. Studies on a non-hernolytic streptococcus isolated from the respiratory tract of human beings. II. Immunological characteristics of Streptococcus MG. J. exp. Med. 80, 407-430.

Mirick, G. S., Thomas, L., Curnen, E. C. and Horsfall Jr., F. L. 1944c. Studies on a non-hemolytic streptococcus isolated from the respiratory tract of human beings. III. Immunological relationship of Streptococcus MG to Streptococcus salivarius type I. J. exp. Med. 80, 431-440.

StoppelaAR, J. D. DE, VAN HouTE, J. and DE MOOR, C. E. 1967. The presence of dextran-forming bacteria, resembling Streptococcus bovis and Streptococcus sanguis, in human dental plaque. Archs oral Biol. 12, 1199-1201.

STRÁlfors, A. 1950. Investigations into the bacterial chemistry of dental plaques. Odont. Tidskr. 58, 155-341.

Strange, R. E., Dark, F. A. and Ness, A. G. 1961. The survival of stationary phase Aerobacter aerogenes stored in aqueous suspension. J. gen. Microbiol. 25, 61-76.

Umbreit, W. W., Burris, R. H. and Stauffer, J. F. 1964. Manometric techniques (4th ed.) Burgess Minneapolis 15, Minnesota.

VAN HouTE, J. 1967. Iodophilic polysaccharide in bacteria from the dental plaque. Thesis, University of Utrecht, The Netherlands.

VAN HouTE, J. and JANSEN, H. M. 1968. The iodophilic polysaccharide synthesized by Streptococcus salivarius. Caries Res. 2, 47-56.

WALKER, G. J. 1966. Metabolism of the reserve polysaccharide of Streptococcus mitis. Biochem. J. 101, 861-872.

Weiss, S., King, W. J., Kestenbaum, R. C. and Donohue, J. J. 1965. Influence of various factors on polysaccharide synthesis in S. mitis. Ann. N.Y. Acad. Sci. 131, 839-850.

WhrTe, J. C. and NIVEN, C. F. 1946. Streptococcus s.b.e.: A streptococcus associated with subacute bacterial endocarditis. J. Bact. 51, 717-722.

Willers, J. M. N., OTtens, H. and Michel, M. F. 1964. Immunochemical relationship between Streptococcus MG, F III and Streptococcus salivarius. J. gen. Microbiol. 37, 425-431. 